\title{
Local Governance Service Delivery Issues during Apartheid and Post- Apartheid South Africa
}

SITHOLE, Sello | MATHONSI, Ntsako

\section{Abstract}

$\mathrm{T}$

e debate on service delivery and governance takes a centre stage

that makes scholars, analysts, across disciplines, schools of thought, commentaries, and media companies countries, and in all platforms where people are able to raise their views on the two subjects. According to scholars and analysts, service delivery and governance are closely related, and in many forms of government, service delivery occurs at the lower sphere which is the sphere closer to communities. The South African context can serve as an exact scenario of this model. This makes local government to be a very important subject on matters of service delivery. worldwide to always keep a close eye on what happens in the country. This becomes clear from the analysis which makes the country to be theorised as a colonisation of a special type. It therefore becomes inevitable to consider the antecedents that shaped the manner in which governance and service delivery were mapped out in South Africa. This paper serves as analysis of local government and service delivery both in apartheid and post-apartheid South Africa. South Africa has an interesting history

Keywords: Local Government, Apartheid, Post-apartheid, Governance, Service Delivery, South Africa. 


\section{Introduction}

The advent of democracy brought hope for improved quality of household life and enhanced service delivery for the majority of South Africans who were crying for survival during the apartheid regime. Twenty one (21) years into democracy, the government seems to be facing challenges to meet the expectations of citizens. Policies, frameworks, and legislations have been put in place by the government to enable effective service delivery to its people (Ngubane, 2005; Pretorius \& Schurink, 2007). Citizens anticipated improved service delivery that would address the evident and persistent legacy of apartheid, especially on the issue of delivery of social services in rural and poor urban areas. To some certain extent, citizens had come to equate the current system of governance with improved service delivery, especially in black communities which were bludgeoned by the evil system of Apartheid. Marginalise citizens argue that this democracy does not translate into improved bread and butter issues as eagerly anticipated. Unmet needs create a groundswell of dissatisfaction and mistrust of the current political system with a soft chorus of Egypt was better.

Service delivery protests punctuate and pervade life in South Africa. Those that are socially excluded do not see much of a difference between the current political dispensation and the previous one. This argument creates a loophole for the credence of the current governance system from citizens' point of view who consider themselves ignored by the government. This paper attempts to make a critical analysis of governance and service delivery during apartheid and post-apartheid, looking at the manner by which local government operates. The start of this exercise will be to define key concepts in the context of this paper.

\section{Definitions of Key Concepts}

As an entry point, it is important to understand what is meant by governance and services and other concepts that are closely related to them. With regards to these two key concepts, there is one striking similarity between them which is the fact that they cannot be defined in explicit terms that command universal acceptance across different disciplines and countries. This is so because the concepts are relative and contextdependant. 
The first key concept is governance, defined as the process of making decision and the process by which those decisions are implemented in institutions (United Nations' Economic and Social Commission for Asia and the Pacific - UNESCAP 2004). UNESCAP (2004) again defines the related concept good governance in terms of the eight major characteristics/factors of decision-making which are participation, consensus, accountability, transparency, responsiveness, effectiveness and efficiency; equitableness and inclusiveness; and the rule of law. The Institute for Democracy in Africa (IDASA) adds two important aspects on the definition of good governance. The two aspects are institutions and systems. IDASA (2010) and Khoza (2013) argue that good governance entails the existence of efficient and accountable institutions and systems and entrenched rules that promote development while ensuring that people are able to participate in, and be heard on, decisions and implementation thereof that directly affect their lives. Finally, one other related concept to governance is government. Government is a set of institutions and concerned body of actors which define how and to what extent the public affairs in societies are shaped and directed (Johnson, 2003; Keman, Sa).

Mohr \& Bitner (1995) defines services as outcomes that customers receive. This definition acknowledges citizens (recipients of services) as customers or clients in tandem with Batho Pele service delivery principles. Important to note in this context is that services can be understood to have the same meaning with public services. The singular form of which is public service, which means a completely different thing in this context. Service delivery is a concept closely related to services as defined above. Fox \& Meyer (1995) define service delivery as the provision of public activities, products, benefits, to satisfy the citizens. In their view, service delivery can either be tangible (products) or intangible (services). A concept related to services and service delivery is public service, which according to Nengwakhulu (2009) is an administrative vehicle by means of which governments deliver all kinds of services to their citizens. In South African context, this definition denotes the arm of the government.

\section{The South African Public Sector}

According to the Institute for Internal Auditors (IIA) (2011), what is understood as public sector is a totality of institutions constituted by governments, government entities, public funded agencies, and companies established in terms of the Acts of Parliament (legislations) and all of which should report to organs of state in one way or the other. 
In other countries, companies that are partly funded by governments are classified under the umbrella of the public sector. The principal function of the public sector is to deliver on public programmes, goods, and services through various kinds of models which include projects, campaigns, programmes, among others, through the vehicle called the public service, as defined earlier. In South Africa, the public sector is configured under the Department of Public Service and administration (DPSA) which is the government Department in charge of ensuring that the entire vehicle is moving effectively. In other words, DPSA should ensure that the spheres of government are in sync from an administration point of view on governance and service delivery at policy and decision making levels. Section 40 (1) of the Constitution of the Republic of South Africa (Act 108 of 1996) provides that government is constituted as national, provincial and local spheres of government which are distinctive, interdependent and interrelated. Each sphere of government may have agencies or entities established in terms of Parliament Legislation in order to assist them to perform on their Constitutional mandates.

It is important to understand that the public sector goes beyond just a mere government since government is part thereof. However, when it comes to service delivery, citizens know the government as the provider of services without understanding the complex value chain of service delivery which implicates the entire public sector. The Institute for Internal Auditors (2011) formulated a set of criteria to be considered in order to contextualise the understanding of the public sector. The criteria developed asks eight (8) questions whose positive answers (yes answer) assist in the classification of whether an institution/company/organisation can be considered as part of the public sector.

The questions that are being asked are:

(i) Does the organisation deliver programs, goods, or services that can be considered a public good or that are established by government policy?

(ii) Is substantially all of the organisation's funding provided by government or determined by government policy?

(iii) Is the organisation accountable to, and does it report directly to government, including a government department or agency, or a minister of government? 
(iv) If the organisation has a board of directors, commission, or similar appointed body, does government control a majority of appointments?

(v) If the organisation has share capital, is government the majority shareholder?

(vi) Are the organisation's employees members of the public service, subject to public service rules, and receiving public service benefits?

(vii) Overall, does government control, directly or indirectly, the organisation's policies, operations, administration, or service delivery?

(viii) Is there a legislative requirement for the organisation to be audited by the government auditor or supreme audit organisation?

The above criteria make it easy to identify whether a company/institution can be classified as part of the public sector or private sector. It should be noted that the private sector is crucial to the existence of the public sector, and vice-versa. This will be argued in terms of Public-Private Partnerships (PPP) for service delivery under possible solutions on challenges facing local government section below.

The Institute of Directors in Southern Africa's King's III (2009), the principles of good governance in the public sector revolve around ensuring that entities/organisations always act in the best interest of the public. Acting in the best interest of the public requires stringent loyalty to integrity, ethical values, rule of law, transparency, and involvement of stakeholders. In addition to the best interest requirement, achieving good governance in the public sector also requires defining outcomes in terms of sustainable socioeconomic and environmental benefits, thereby determining the interventions that are necessary to optimise the achievement of intended outcomes. It also requires capacity development for entities, including the capability of its leadership and the individuals within it for managing risks and performance through vigorous internal controls and strong public financial management. Finally, it requires implementing of best practices in transparency and reporting to deliver effective accountability (The Chartered Institute of Public Finance and Accountancy \& the International Federation of Accountants, 2013).

In South Africa, the public sector is organised under sub-sectors that are commonly known as government clusters which are constituted by various departments which are 
members of the clusters. According to SaNews (2014), the Presidency announced the government clusters which have been constituted to improve coordination within government and enhance the delivery of services. The clusters are:

(i) Economic Sectors, Employment and Infrastructure Development, chaired by the Minister of Rural Development and Land Reform.

(ii) Governance and Administration Cluster, chaired by the Minister of Public Service and Administration.

(iii) Social Protection, Community and Human Development, chaired by the Minister of Basic Education,

(iv) International Cooperation, Trade and Security, chaired by the Minister of Telecommunications and Postal Services.

(v) Justice, Crime Prevention and Security, chaired by the Minister of Defence and Military Veterans.

Each cluster is rationalised to consist of departments whose mandate are related to a certain extent. As such, clusters are designed to address particular issues in their own ways for the public sector. In the spirit of cooperative governance, the three spheres of government work together on policy, coordination, and service delivery issues. As the three spheres of government work together, organisations and institutions are involved, and consequently services are delivered at the lower sphere of government which is called local government. Local government in South Africa is constituted by 278 municipalities organised under one association called the South African Local Government Association (SALGA), which is a key member/stakeholder in policy engagements in nearly all sector departments.

\section{Local Government System in South Africa}

According to Ngubane (2002) and Powell (2012), the evolution of local government in South Africa dates back to the $17^{\text {th }}$ and $18^{\text {th }}$ centuries which is the period when the Dutch East India Company (DEIC) and the British Settlers arrived in the Cape, respectively. They also argue that the influence of the Dutch and English respectively culminated in the development of a hybrid local government system in South Africa. The white regime considered the $18^{\text {th }}$ century period as a significant improvement of the 
South African government system because it introduced the three level/tiers of government which are the national, provincial and local government administration. The introduction of the three-tier government system was assimilated into the Apartheid system which was racially based and characterised by exclusive authorities for various racial groups. During this period, local government in most rural areas where blacks resided was almost non-existent (Ngubane, 2002).

The history of local government transition in South Africa makes it clear that the local government system came into being even before 1948 when the apartheid governance system was officialised, and unfortunately segregation was already a salient aspect of local government even then. According to the White Paper on Local Government (1998), segregation was already an applied policy by the time apartheid was introduced in 1948 . The Group Areas Act, 1950 (Act 41 of 1950) introduced rigorous segregation of people in terms of their areas of residence and forceful removal of black people to "own group" areas. The Apartheid system sought to avoid a situation wherein wealthy white municipalities would have a burden of providing services to areas inhabited by black people. Thus the Group Areas Act restrained permanent abode for blacks in urban areas where people resided through the pass system, and reserved a viable municipal revenue base for white areas by separating townships, industrial, and commercial development areas (Department of Provincial and Local Government 2008).

A number of attempts were made under the apartheid system to introduce "own management" structures for black residents at the local level. This was in part to compensate for restricted rights, and in part to bolster the political and economic privileges of racial exclusion. According to the White Paper on Local Government (1998), this is what was done:

(i) In Bantustans (separate homelands for Northern and Southern Sothos, Swazis, Tsongas, Tswanas, Vendas, Xhosas, and Zulus - each with its own Bantu Authority), a limited local government was established. Traditional leaders were given powers over land allocation and development matters in areas with communally owned land. Some small rural townships (the so-called "R293 towns") were given their own administrations, but these lacked legitimate powers. 
(ii) In the 1960s, "Coloured" and "Indian" management committees were established as advisory bodies to white municipalities.

(iii) The Bantu Affairs Administration Act of 1971 established and appointed Administration Boards, which removed responsibility for townships from white municipalities.

(iv) In 1977, Community Councils were introduced. Community Councils were elected bodies, but had no meaningful powers and few resources. They never gained political credibility.

(v) In 1982, Black Local Authorities replaced Community Councils. Black Local Authorities had no significant revenue base, and were seen as politically illegitimate from the start. They were rejected sometimes violently by the community through mass mobilisation in the mid-1980s.

Government services were seen then as either an own affair or a general affair. The tricameral parliament was based on a concept of groups with their own racial and cultural identities, and distinguished between general affairs and own affairs, the former affecting all population groups and the latter confined to issues affecting only those groups.

Own affairs would 'affect a population group in relation to the maintenance of its identity and the upholding and furtherance of its way of life, culture, traditions and customs' (Welsh). These included issues related to social welfare, education at all levels, health, community development (including housing), local government (within areas designated for the respective population groups) and agriculture, including financial assistance to farmers (http://www.sahistory.org.za/article/1983-constitution-and-newdispensation).

To some extent these forms of "own local government" were designed to reinforce the policies of segregation and economic exclusion. None had resources to make any real difference to the quality of life of their constituents (The White Paper on Local Government 1998).

With regard to the transition of local government in South Africa, according to Powell (2012) and the SALGA (2015), the transition period of the South African local 
government occurred in three phases/stages. Without delving into details of the phases, an outline of key activities that occurred in each phase is hereby provided.

During the first phase, the coming into operation of the Local Government Transition Act (LGTA) 1993, (Act 209 of 1993) and the establishment of the negotiating fora in local authorities pending the first local government election occurred. The second phase commenced when the first local government elections were held in 1995/1996, establishing integrated municipalities even though these were not yet fully democratically elected. The third and final phase started with the local government election on 05 December 2000, where establishing the current municipalities were established. Underpinning this transition process were the interim Constitution of 1993 and the final Constitution of 1996. The most notable transformation of local government system commenced in 1998 with the demarcation of fully integrated municipalities with functions covering the total geographic area of South Africa (Cloete, De Villiers, Hoffschulte, Magi, Malherbe, Naidu, \& Thornhill, 2008; Powell, 2012).

The current local government system in South Africa finds its legislative expression (principally) from the following Acts of Parliament, among others:

(i) The Constitution of the Republic of South Africa Act, 1996 (Act 108 of 1996)

(ii) Local Government: Municipal Systems Act, 2000 (Act 32 of 2000)

(iii) Local Government: Municipal Structures Act, 1998 (Act 117 of 1998)

(iv) Traditional Leadership and Governance Framework Act, 2003 (Act 41 of 2003)

(v) Municipal Finance Management Act, 2005 (Act 13 of 2005)

(vi) Intergovernmental Relations Framework Act, 2005 (Act 13 of 2005)

(vii) Municipal Demarcation Act, 1998 (Act 27 of 1998).

Municipalities, as part of government institutions/entities, should ensure access to services by all citizens including those that were classified as previously disadvantaged (Helmsing, 2000). As local government entities, they have an obligation to structure and manage their administration, budgeting, and planning so as to give priority to basic needs and services of citizens and encourage socioeconomic development of communities. Municipalities are also obliged to participate in national and provincial development programmes delegated to be administered in local government (Municipal Systems Act, 2000; Act 32 of 2000). The local government's role is considered in terms 
of its functions and powers, some of which are decentralised from both the national and provincial governments.

The developmental role of the local government (as introduced in the White Paper on Local Government 1998) is core to the functions of municipalities. Democratising local government is also discussed in the White Paper since it measures the local government's openness and transparency in fulfilling its mandate which affords communities an opportunity to participate on the matters that affect their lives, issues such as service delivery and local economic development, among others. Funding for the local government is also dealt with since it plays a very vital role in ensuring that the local government is able to deliver services effectively and efficiently (The Presidency, 2010; Ngubane, 2005).

The sphere closer to the communities and best placed to fulfil government's responsibility of providing services is the local government. Local government forms part of the public sector which is closest to the inhabitants and is, therefore, indispensable in its role of providing essential goods and services and developing the local environment. This signifies major importance of municipalities since they are at the forefront of service delivery. Mkentane (2013) argues that municipalities are at the forefront of service delivery. This means that they are not only charged with a direct responsibility of government delivery but are also closer to the people and have to face up the challenges and demands for services by the communities.

\section{Service Delivery in Apartheid South Africa}

The Presidency conducted a twenty-year review of democracy in South Africa and produced a document that, among other important matters, summarises the manner in which services were delivered during Apartheid in South Africa. According to the Presidency (2015), homelands principally served as labour pool/reservoirs for "whites" in South Africa to store black people and release them from time to time into white areas/towns whenever their workforce was needed. Through the homelands system, the apartheid government sought to serve the mining industry's labour requirements as well as those of farmers and other white-owned businesses while at the same time retaining white political dominance in the Country. Homelands, where most blacks resided were characterised by marginal lands with low production capacity which were unable to develop local economies, and this made the homelands to depend on the apartheid 
state for funding. Due to a lack of resources, issues of corruption, and a lack of legitimacy of the homeland administrations, huge backlogs figures on basic services such as water, electricity, health, and education facilities started to escalate in homelands. The impact of this legacy is currently being experienced (Treiman, 2005 and Nnadozie, 2013).

Most homelands were not provided with access to basic municipal services such as clean water, sanitation, refuse removal, and electricity. These municipal services were often non-existent as opposed to areas where whites inhabited. In black urban areas, if such services existed, they often did not meet basic needs and were often sporadic and irregular. The lack of basic services contributed to high incidents of water-borne diseases such as diarrhoea and cholera in homelands. The dearth of electricity resulted in people using coal stoves which contributed to an increase of respiratory diseases and conditions. While most black people had to travel long distances to get to their places of work because of apartheid spatial patterns, the state did not provide safe, reliable, adequate and affordable means of transport (The Presidency, 2015).

According to the Presidency (2015), most local government revenue in urban South Africa was self-generated, mainly through business, property taxes and through the delivery of services to residents. This phenomenon appositely suited white municipalities which had small populations to provide for and large concentrations of economic resources to tax. Financial shortfalls were built into local government for black areas. Apartheid regulations barred most retail and industrial developments in black areas. This limited the tax base and forced residents and retailers to spend most of their money in white areas. Municipalities in black areas were therefore deprived of the means to meet the needs of local residents. In rural areas, discrimination and segregation were equally stark. Water and electricity were supplied to white residents in rural areas at enormous cost, while scant regard was given to the needs of the rural majority. Black Local Authorities attempted to impose rent and service charges on township residents to increase revenue. This revenue source could never have provided for meaningful delivery since it only served to annoy increasingly politicised communities (The Presidency, 2015).

It is clear that service delivery was a challenge during the Apartheid regime especially in homelands where black people resided. It was most unfortunate that their voices and dissatisfaction about poor service delivery fell on deaf ears. The inevitable was that poor service delivery became a 'normal' way of life. This was so especially due to the fact that, at that time, there was little hope for an alternative system of governance. On the flip 
side of it, the white minority citizens (in population) had nothing to worry about regarding service delivery matters.

The debate of whether service delivery in the democratic South Africa is following the reverse Apartheid trend especially in terms of prioritisation as opposed to quality is an interesting one, and it becomes important for actors to carefully consider the difference between the manner in which services were delivered during apartheid and now.

\section{Service Delivery in Democratic South Africa}

In 1997-98, the Department of Public Service and Administration (DPSA) published the White Paper on the Transforming Public Service Delivery that outlines the eight (8) principles known as Batho Pele Service Delivery Principles. Batho Pele is a Sotho phrase that is interpreted/translated to "People First." This was a first initiative of its own kind where the public sector was given principles to adhere to as goods and services are delivered to the citizens. The nature of the principles assists the public service to consider citizens as customers/clients of the public sector.

The eight principles are:

(i) Information: People/citizens should be provided with information about the level and quality of service. Citizens should not only be given feedback when there is good news but they have to be notified even when there are challenges.

(ii) Openness and Transparency: All government operations should be undertaken in an open and transparent manner, unless if such undertakings are of a sensitive nature. This will ease the minds of citizens and minimise fraud and corruption.

(iii) Consultation: the citizens/ consumers will be consulted on the level and quality of service that they receive and on matters that affect them.

(iv) Courtesy: All public officials shall behave in a polite and altruistic manner when interacting with and rendering service to the public. This can translate into a warm and caring attitude towards customers. 
(v) Access: All citizens shall have equal access to services and shall not be discriminated against on any grounds.

(vi) Service standard: Citizens shall be made aware of the level and quality of service that they will receive.

(vii) Redress: The Apartheid government rendered quality service to a particular segment of the population. The Black and rural communities remained underserviced. The Government of the day is committed in rectifying the inequalities of the past. This could be achieved by prioritising the needs of the previously disadvantaged in the delivery of services.

(viii) Value for Money: This principle emphasises effectiveness and efficiency. Resources are never abundant; the available resources should be put to good use. This translates into better results and efficient service delivery at minimal costs.

The White Paper on the Transforming Public Service Delivery (1997:4) provides that:

Public services are not a privilege in a civilised and democratic society; they are a legitimate expectation. That is why meeting the basic needs of all citizens is one of the five key programmes of the government's Reconstruction and Development Programme (RDP). It is also the reason why the Government's macro-economic strategy called Growth, Employment and Redistribution (GEAR) calls, among other things, for the reduction in unnecessary government consumption and the release of resources for productive investment and their redirection to areas of greatest need. This means that government institutions must be reoriented to optimise access to their services by all citizens, within the context of fiscal constraints and the fulfilment of competing needs.

It is always important to consider what the legislation says with regards to the delivery of services. This will assist policy makers, governments, citizens, and interested parties to identify whether the public sector is winning the battle against changing the apartheid trend legacy in the delivery of services. Section 73 of the Local Government Municipal Systems Act, 2000 (Act 32 of 2000) provides that a municipality must give effect to the provision of the Constitution and: 
(i) give priority to the basic needs of the local community;

(ii) promote the development of the local community; and

(iii) ensure that all members of the local community have access to at least the minimum level of basic municipal services.

Municipal services must, therefore:

(i) be equitable and accessible;

(ii) be provided in the manner that is conducive to the prudent, economic, efficient and effective use of available resources and the improvement of standards of quality over time;

(iii) be financially sustainable;

(iv) be environmentally sustainable; and

(v) be regularly reviewed with a view to upgrading, extension and improvement.

Whether or not the above legislation provisions are translated into concrete visible services does not need rocket science. By mere observation, it can be inferred that it is not happening according to plan. However, it is important to note that municipalities /local governments are faced with a number of challenges that account for the slow and irregular pace towards implementing the legislated provision. This is where challenges such as capacity constraints, funding mechanisms, political-administrative incoherence, and governance come to the fore, and make it difficult to argue that the public sector is failing when it comes to the delivery of services beyond just a mere observation of what is happening. Cadre deployment has also been associated with poor service delivery. Cadre deployment is a practice of appointing the ruling party's loyal supporters. Whereas there is absolutely nothing wrong with appointing people whose loyalty is to the ruling party; it is problematic when those cadres are not adequately skilled and appointed into positions where they are forced to swim or drown. And in most cases, the latter is the case.

Very crucial to note is that the entire value chain of service delivery terrain is not as simple as it seems from an observer point of view. A lot of issues such as establishing community task teams on services and ensuring functionality of such task teams are some of which are beyond the control of the public sector which come into play and 
account for this terrain to be a challenging one. In such a case, communities can just set up a task team that can work with Community Development Workers (CDWs), Ward Committees (WCs), and councillors on matters of service delivery and other community development-related issues. Within its power, the public sector introduced a policy framework in 1994 with a hope that there will be a radical change that will affect the entire citizenry of South Africa positively from a service delivery point of view, among other important matters. Nnadozie (2013) and Visser (2004) argue that from the beginning of the Reconstruction and Development Program (RDP) of the African National Congress (ANC)-led government, there was an expectation that the goals set out in the national development framework would be achieved as planned. For example, the stated target was to provide all households with a clean and safe supply of 25 litres of water per capita per day (within 200 meters of the household) as well as improved sanitation facilities. Besides the targets of the RDP, there were other development commitments from various quarters which included the service delivery targets of former President Mbeki (Mbeki 2004), articulated in one of the most noteworthy State of the Nation addresses in 2004 (ten years into democratic South Africa). He argued that these related to the key issues around household services provision, education, health care, and security amongst others and were premised on the expectation that they would be provided speedily (Nnadozie, 2013). The promises included intensifying the housing programme and the delivery of piped water to all households in South Africa within the five-year period that was to come (2008/9) (Mbeki 2004).

The RDP policy framework emphasised the role of local government (municipalities) in this process based on the premise that the democratic government will reduce the burden of implementation which falls upon its shoulders through the appropriate allocation of powers and responsibilities to lower levels of government (ANC, 1994). This emphasis was given sharper focus in the White Paper on Local Government, which held that local government must cooperate with local communities to find sustainable ways to meet their needs and improve the quality of their lives (White Paper on Local Government, 1998).

Given the challenges associated with the delivery of services, it should be noted that the public sector has tried its utmost best to deliver services, and it remains the goal of the public sector to achieve an ideal situation of universal access to basic services by all citizens. Powell (2012) makes a brief review of what the government has achieved thus 
far from a delivery of basic services point of view by looking at selected service items. He argues that there has been a significant progress of $93 \%$ of the population which now have access to a basic level of water (meaning a stand pipe within 200 metres from a dwelling according to CoGTA, 2011), $85 \%$ of households have access to electricity, $67 \%$ of households have access to basic sanitation (a ventilated pit latrine in the dwelling); and $62 \%$ to once a week refuse removal (CoGTA, 2014).

The brief review above by Powell (2012) and CoGTA (2009) gives an indication that there is something that the public sector can pride itself on regarding delivery of basic services, although there is still a long way to go. There will still be policies and implementation guidelines that will be further developed to ensure that basic services are delivered to the people. This is in short what was said by President Jacob Zuma:

We make a commitment here and now, before the eyes of the world, that: For as long as there are South Africans who die from preventable disease; for as long as there are workers who struggle to feed their families; for as long as there are communities without clean water, decent shelter or proper sanitation; for as long as there are rural dwellers unable to make a decent living from the land on which they live; for as long as there are women who are subjected to discrimination, exploitation or abuse; for as long as there are children who do not have the means nor the opportunity to receive a decent education; for as long as there are people who are unable to find work, we shall not rest, and we dare not falter" (Zuma, 2009).

From the commitment that the government will not rest until the universal access to basic services to citizens is achieved, CoGTA has conducted a study to review performance, governance, and service delivery issues, among others important matters, for the 278 municipalities. The study revealed that there is still a long way to go towards reaching the ideal standards of municipalities that the public sector envisages. CoGTA (2014:4-5) summarises the outcome of the review as follows:

The top third municipalities have got the basics right and are performing their functions at least adequately. Within this group, there are a small group of top performers that are doing extremely well. In these municipalities, there are innovative practices to ensure sustainability and 
resilience. This small core represents the desired (ideal) state for all our municipalities. The middle third of municipalities are fairly functional, and overall performance is average. While the basics are mostly in place and the municipalities can deliver on the main functions of local government, we also find some areas of poor performance or decline that are worrying signs. The bottom third of municipalities are frankly dysfunctional, and significant work is required to get them to function properly. Among others we find endemic corruption, councils which don't function, no structured community engagement, and poor financial management leading to continuous negative audit outcomes. There is a poor record of service delivery, and functions such as fixing potholes, collecting refuse, maintaining public places or fixing street lights are not performed. While most of the necessary resources to render the functions or maintain the systems are available, the basic mechanisms to perform these functions are often not in place. It is in these municipalities that we are failing our people dramatically, and where we need to be intervening urgently in order to correct the decay in the system.

CoGTA (2014) mentions challenges of institutional incapacity and widespread poverty which have undermined the sustainability of the local government project, leading in some instances to a serious breakdown of service delivery. Other challenges faced are:

(i) A collapse in core municipal infrastructure services in some communities, resulting in services either not being provided at all, or provided at unacceptably low levels.

(ii) Slow or inadequate responses to service delivery challenges are in turn linked to the breakdown of trust in the institutions and councillors by communities.

(iii) Social distance by our public representatives is a major cause for concern. This reflects inadequate public participation and poorly functioning ward councillors and committees. 
(iv) The viability of certain municipalities is a key concern. The low rate of collection of revenue continues to undermine the ability of municipalities to deliver services to communities.

(v) Municipalities also need to be driven by appropriately skilled personnel and their correct placement, and there are for too many instances both of inappropriate placements and skills not measuring up to requirements.

(vi) This is compounded by widespread instances of rent seeking and corruption amongst public representatives and business, reflecting a broader breakdown in the values and good governance principles that should be guiding the people we have elected or appointed to run the local government system and those that do business with government (CoGTA, 2014).

Managa (2012) agrees with the findings by CoGTA as he argues that among the major challenges facing local government are severe problems of institutional capacity, mismanagement of funds, high levels of corruption and a lack of public participation. These are key challenges hampering performance at the local government sphere. Wild, Chambers, King and Harris (2012) conducted an assessment across the range of sectors and country and a number of common issues/challenges were identified. These seem to arise time and again in different sectors and contexts, and are associated with detrimental impacts on service delivery outcomes. They include cases where politicians use services as patronage tools, where there are mismatches between national and local government strategies and policy frameworks, and where users themselves opt out of formal provision and instead rely on unregulated informal providers.

\section{Possible Solutions to Challenges Facing the Local Government}

Scholars, analysts, citizens, governments, and interested parties have identified a number of solutions that can be explored to address some of the challenges that were identified in the review conducted by CoGTA. Managa (2012) raises a number of actions to be implemented to address the challenges facing local government. He argues that in order to address the poor state of our municipalities, the following be implemented:

(i) Strengthen human and resource capacity, which will enable local government to deliver its constitutional mandate to the public. 
(ii) Recognise and address the fact that the 'one size fits all' approach does not work for all municipalities, as communities have different needs according to their geographical areas.

(iii) Strengthen national and provincial oversight and supervision of local government affairs, which will enable prompt intervention to take place.

(iv) Make and honour commitments to root out nepotism and corruption in areas such as recruitment for municipal positions and the awarding of tenders for services.

(v) Hold senior officials accountable when they fail to disclose their business or pecuniary interests.

(vi) Strengthen government procurement procedures and policies and accountability.

Ngubane (2005) and Zubane (2011) indicate that municipalities are responding to the challenge of poor service delivery by exploring Public-Private Partnerships (PPPs) as a way to improve the delivery of services. This approach provides an opportunity where the public sector works together with the private sector to address the challenge of service delivery. It is commonly known that the private sector amassed a lot of skills and expertise that could be useful in the service delivery terrain, thus through the PPPs such relations are strengthened. This approach also uses the expertise, investment, and management capacity of the private sector to develop infrastructure as well as to improve and extend efficient services to all residents, while skills transfer between the private and public sectors occurs.

From a point of view that one among the causes of community protests is poor engagement/lack of public participation by municipalities, Nnadozie (2013) and (Ngubane 2005) argue that there is therefore a need for continued and intensified involvement of communities by employing platforms like izimbizo (gatherings), ward committees, youth meetings and women's assemblies, amongst others. Such platforms should focus not only on the politics behind the allocation of service units, but should also promote information sharing on the logistics and limitations of local governments towards the delivery of expected services (Nnadozie, 2013). Ngubane (2005:139) further concretise his argument for public participation by arguing that municipality should 
engage with communities about services that will be rendered to them in order for communities to indicate the form, level, and type of services they would need for themselves, and he further outlines a model for an ideal value chain of delivery of services:

$>$ Step 1: Consultation

$>$ Step 2: Service Discussion

$>$ Step 3: Implementation - Service Delivery Standards

$>$ Step 4: Monitoring - Capacity Building

$>$ Step 5: Performance Management - Capacity Building

$>$ Step 6: Evaluation (Review) (Ngubane, 2005)

Powell (2012) and the World Bank (2009) argue that there should be improvement on administrative capacity and financial management, which is one area where even municipalities themselves would argue to say there are no funds and capacity enough to take care of their responsibilities. Availability of funds and capacity to manage those funds to deliver according to the mandate are very important to be ascertained for availability for municipalities to perform. As the custodian of municipal governance of service delivery for the sector, CoGTA (2014) raises a subject that can be argued as an ignored aspect in the governance and service delivery value chains, which is the involvement of traditional leaders. Harmonising/streamlining cooperation between traditional leaders and municipalities to advance development and service delivery is very important. To give effect to this harmonisation, the Department of Traditional Affairs has developed a comprehensive framework for the participation of traditional leaders in municipal councils to harmonise relations between traditional structures and municipalities. The roles of traditional leaders in municipal affairs include their role to facilitate the participation of traditional communities in any municipal activities that allow for public participation.

In keeping with the Back to Basics approach by CoGTA, municipal and traditional structures should establish strong collaborative working relationships to create decent living conditions and improve delivery of services to rural traditional communities. This collaboration must result in the following actions:

(i) Traditional structures must participate in municipal council sittings (where applicable). 
(ii) Traditional leaders must participate in Integrated Development Plans of municipalities and related community consultation processes. Local Government Back to Basics Strategy.

(iii) Traditional Leaders must facilitate access and release of land for development purposes.

(iv) Traditional leaders must align release of land with spatial development plans of municipalities (e.g. demarcation of plots).

(v) Municipalities must involve traditional structures in programmes impacting on traditional communities.

\section{Conclusion}

It is conspicuous that the Apartheid system left behind both the legacy and footprints of inequalities in access to services that prevail to date. However, it is also clear that the government have not rested to fight against the apartheid legacy to an extent that it is clear that some positive progress have been noted. Therefore, an argument that says nothing has changed since the new system of governance was introduced is fallacious and might lead to mistrust of the government by citizens on baseless grounds. It should be considered that the fourth term of government took office with the economy in recession and under enormous pressure to combat job losses due to economic meltdown, and with the Ruling Party's internal factions, however, the government remain focused and determined to deliver services to the citizens.

The government introduced the National Development Plan (NDP) 2011, to serve as a framework for policy formulation towards achieving the vision 2030. As indicated earlier, policies on governance and service delivery will be developed and enhanced until the goals of the RDP frameworks are achieved. It should be noted that policies are inherently for a particular purpose at a particular time. There is no policy that remains the same throughout the course of life. As things change, responses through drafting of policies should be made to ensure relevance. The overall objectives of policies is for improving and sustaining the quality of all public services, ensuring that services are delivered in order to meet social needs, and to ascertain access to services for all citizens who need them, as well as equitable allocation of resources. 
Once again, it is important to note that there is crucial relationship between governance and service delivery. The extent to which there are deficiencies in municipal governance is the same extent to which service delivery is being suffocated, which results in community protests. The incidents of service delivery protests witnessed all over the country is an indication that things have changed and people have a right to voice their opinions even when it comes to the delivery of services, which is one of the rights that was never enjoyed during the apartheid regime. It therefore becomes important to appreciate the fact that work is being done by the government regardless of the financial constraints and other challenges beyond the control of government. South Africa's democracy can be compared with other countries that attained their freedom and democracies much earlier, and it can be demonstrated that South Africa is better compared to some of those countries when it comes to issues of governance and service delivery. Therefore, while it is important to critique the public sector and its governance, it is also important to note the job well done until this 21st year after the advent of democracy.

\section{List of References}

- AfRICAN NATIONAL CONGRESS. 1994. The Reconstruction and Development Programme: A Policy Framework. Johannesburg: Umanyano Publications.

- BYNOE, I. 1996. Beyond the Citizen's Charter: New Directions for Social Rights. London: IPPR.

- Cloete, F., De Villiers, B., hOfFSChUlte, H., MAGI, L., MALheRBE, R., NAidU, R., \& THORNHILL, C. 2008. Review of provinces and local governments in South Africa: Constitutional Foundations and practice. Occasional Papers. Johannesburg: KonradAdenauer-Stiftung.

- DEPARTMENT OF COOPERATIVE GOVERNANCE AND TRADITIONAL AFFAIRS. 2009. Basic services publication: comparative information on basic services. Pretoria: CoGTA. 
- DEPARTMENT OF COOPERATIVE GOVERNANCE AND TRADITIONAL AFFAIRS. 2011. Presentation: Programme of Action Progress: April-September 2010, 8 February 2011. Parliament: COGTA.

- dePARTMENT OF COOPERATIVE GOVERNANCE AND TRADITIONAL AFFAIRS. 2014. Back to Basics. The Presidential Local Government Summit. Serving Our Communities Better! Pretoria: CoGTA.

- FOX, W. \& MEYER, IH. 1995. Policies for Public Service Transformation. Eliot Avenue: Creda Press.

- HELMSING, AHJ. 2000. Decentralisation and Enablement, Issues in the Local Government Debate. Inaugural address, 27 April 200. Utrecht: Utrecht University.

- JOHNSON, N. 2003. State Welfare. In The Student's Companion to Social Policy.2 ${ }^{\text {nd }}$ Edition. Edited by Pete Alcock, Angus Erskine and Margaret May. Oxford. Blackwell Publishing

- KEMAN, H. (Sa). Structure of Government. Government and Politics. Vol. I. Free University Amsterdam. Accessed on 20/04/2015 from http://www.eolss.net/sample-chapters/c04/e632-02.pdf

- KHOZA. NJ. 2013. Examining the Relationship between Good Governance and Development: The Case of the African Peer Review Mechanism (APRM). A research report submitted to the Faculty of Humanities, University of the Witwatersrand, in partial fulfilment of the requirements for the degree of Master Arts in International Relations Johannesburg: University of Witwatersrand.

- MANAGA, A. 2012. Unfulfilled promises and their consequences: A reflection on local government performance and the critical issue of poor service delivery in South Africa. Africa Institute of South Africa AISA Policy brief Number 76 - May 2012

- MBEKI, T. 2004. Address to the First Joint Sitting of the Third Democratic Parliament of South Africa. Cape Town: Parliament of the Republic of South Africa.

- MOHR, LA. \& BITNER, MJ. 1995. "The Role of Employee Effort in Satisfaction with Service Transactions." Journal of Business Research, 32(3), 239-252.

- MKentANe, B Z. 2013. An Investigation of Public Participation in Municipal Planning and Performance Evaluation: "A Case of Mnquma Local Municipality. A Dissertation Submitted in Fulfilment of the Requirements for the Degree of Master of Public Administration in the Faculty of Management and Commerce at the University of Fort Hare. East London: University of Fort Hare. 
- NengWAKHUlU, RH. 2009. Public Service Challenges Facing the South African Public Service. Journal of Public Administration. Volume 44(2).

- NGubANE, MB. 2005. An Evaluation of Service Delivery at Ndondakusuka Local Municipality. Submitted in fulfilment of the requirements for the degree of Doctor of Administration in the discipline of Public Administration in the Faculty of Commerce, Administration and Law at the University of Zululand.

- NNADOZIE, RC. 2013. Access to basic services in post-apartheid South Africa: What has changed? Measuring on a relative basis. The African Statistical Journal, Volume 16, May 2013. Pp 81-103

- POWELL, D. 2012. Imperfect transition - local government reform in South Africa 19942012.Local Elections In South Africa: Parties, People, Politics. SUN Media Metro and authors.

- PRETORIUS, D. \& SCHURINK, W. 2007. Enhancing Service Delivery in Local Government: The Case of a District Municipality. Department of Human Resource Management University of Johannesburg.

- REPUBLIC OF SOUTH AFRICA. 1996. The Constitution of the Republic of South Africa Act, 1996 (Act 106 of1996). Pretoria: Government Printers.

- REPUBLIC OF SOUTH AFRICA. 1997. The White Paper on Transforming Public Service Delivery, 1997. Pretoria: Government Printers.

- RePUBliC OF SOUTH AfRiCA. 1998. White Paper on Local Government, 1998. Pretoria: Government Printers.

- REPUBliC OF SOUTH AFRICA. 2000. The Local Government Municipal Systems Act, 2000 (Act 32of 2000). Pretoria: Government Printer.

- SANEWS. 2014. Newly constituted ministerial clusters announced. Accessed on 20/04/2015 from http://www.sanews.gov.za/south-africa/newly-constituted-ministerial-clustersannounced.

- STEytleR, N. \& POWELL, D. 2010. The Impact of the Global Financial Crisis on Decentralised Government in South Africa. L'Europa en formation 358 (Winter): 149-172.

- the chartered institute of public finANCE AND ACCOUNTANCy \& THE INTERNATIONAL FEDERATION OF ACCOUNTANTS. 2013. Good Governance in the Public Sector - Consultation Draft for an International Framework. New York: International Federation of Accountants (IFAC). 
- THE INSTITUTE FOR DEMOCRACY IN AFRICA. 2010. The State of Local Government and Service Delivery in South Africa: Issues, Challenges and Solutions. Submitted to the Portfolio Committee on Cooperative Governance and Traditional Affairs (CoGTA) for Public Hearings, Coordinated Service Delivery on 22 January 2010. Cape Town.

- THE INSTITUTE OF INTERNAL AUDITORS. 2011. Supplemental Guidance: Public Sector Definition. Accessed on 25/04/2015 from http://www.theiia.org/leaderslink/index.cfm?iid =716\&catid $=0$ \&aid $=3681$

- THE PRESIDENCY. 2015. Delivery Agreement for Outcome 9: A Responsive, accountable, effective and efficient local government system. Final, 30 September 2010. Accessed on 01/05/2015 from http://www.gov.za/sites/www.gov.za/files/outcome-9_deliveryagreement.pdf

- THE PRESIDENCY. 2015. Twenty Year Review South Africa. 1994 - 2014. Accessed on 21/04/2015 from http://www.thepresidency-dpme.gov.za/news/Pages/20-Year-Review.aspx

- $\quad$ the SOUth AfRicAN local GOVERnMENT ASSOCiation Website. 2015. Municipalities - About Municipalities. Accessed on 20/04/2015 from http://www.salga.org.za/pages/Municipalities/About-Municipalities

- THE WORLD BANK. 2009. Improving Municipal Management for Cities to Succeed An IEG Special Study. Conference Edition. Washington, DC: The International Bank for Reconstruction and Development.

- TREIMAN, DJ. 2005. The Legacy of Apartheid: Racial Inequalities in the New South Africa. Department of Sociology. Oxford: Oxford University Press.

- UNITED NATIONS' ECONOMIC AND SOCIAL COMMISSION FOR ASIA AND THE PACIFIC. 2004. What is Good Governance? United Nations Economic and Social Commission for Asia and the Pacific. Accessed on 13/10/2010 from http://www.unescape.org/huset/99/governance.htm.

- VISSER, W. 2004. "Shifting RDP Into GEAR". The ANC Government's Dilemma In Providing an Equitable System of Social Security for the "New" South Africa. University of Stellenbosch. Paper presented at the 40th ITH Linzer Konferenz, 17 September 2004.

- Wild, L., CHAMBerS, V., KING, M., AND HARRIS, D. 2012. Common constraints and incentive problems in service Delivery: Working Paper 351. London: Overseas Development Institute.

- ZUBANE, P. 2011. Alternative Service Delivery Models For The South African Public Service For The Year 2020. Research report presented in partial fulfilment of the requirements for 
the degree of Master of Future Studies at the University of Stellenbosch. Cape Town: Stellenbosch University.

- ZUMA, JG. 2009. Address by His Excellency Mr Jacob Zuma on the occasion of his Inauguration as fourth President of the Republic of South Africa, 09 May 2009. Cape Town. Accessed on 25/04/2015 from

http://www.thepresidency.gov.za/pebble.asp?relid $=762$

AUTHORS' CONTACT:

SITHOLE, S.L. $\mid$ MATHONSI, N.S.

Director of the School of Social Sciences University of Limpopo Email: sello.sithole@ul.ac.za
Dept of Sociology

University of Limpopo

Email: buqedaka@gmail.com 